\title{
28 Resarch Soure \\ PTP4A2 regulates Sorafenib resistance via activating autophagy in hepatocellular carcinoma
}

\section{Research}

Keywords:

Posted Date: September 29th, 2020

DOI: https://doi.org/10.21203/rs.3.rs-66927/v2

License: (c) (i) This work is licensed under a Creative Commons Attribution 4.0 International License.

Read Full License 


\section{Abstract}

The authors have requested that this preprint be withdrawn due to author disagreement.

\section{Full Text}

The authors have withdrawn this preprint from Research Square. 